RASĀYAN J. Chem.

Vol. 14 | No. 2 |676-683| April - June | 2021

ISSN: 0974-1496 | e-ISSN: 0976-0083 | CODEN: RJCABP

http://www.rasayanjournal.com

http://www.rasayanjournal.co.in

\title{
LIQUID CHROMATOGRAPHY-MASS SPECTROMETRY CHARACTERIZATION OF BIOACTIVE COMPOUNDS FROM Sargassum polycystum WITH THE LARVAL AND IN VITRO ANTICANCER ACTIVITY
}

\author{
F. J. Sami ${ }^{1,2}$, N. H. Soekamto ${ }^{2, \bigotimes}$ Firdaus $^{2}$ and J. Latip ${ }^{3}$ \\ ${ }^{1}$ Department of Pharmaceutical Chemistry, Sekolah Tinggi Ilmu Farmasi, \\ Makassar 90242, Indonesia \\ ${ }^{2}$ Department of Chemistry, Hasanuddin University, Makassar 90245, Indonesia \\ ${ }^{3}$ School of Chemical Sciences \& Food Technology, Universiti Kebangsaan Malaysia, \\ Selangor 40542, Malaysia \\ ${ }^{\circledR}$ Corresponding Author: nunukhariani@unhas.ac.id
}

\begin{abstract}
Sargassum polycystum is a type of seaweed that has been widely used in traditional medicine. This study examines the cytotoxic effect of $S$. polycystum extracts against $A$. salina and the active extract was then fractionated Liquid Vacuum Chromatography (LVC). The fraction was the evaluation of anticancer potential against lung and breast cancer cells in vitro and their chemical components of fractions by LC-MS Bruker micrOTOF-mass spectrometer (ESI -) technique. Ethyl acetate extract was very toxic activity against $A$. salina with $\mathrm{LC}_{50}$ values of $12.37 \mu \mathrm{g} / \mathrm{mL}$ compared to n-hexane with $\mathrm{LC}_{50}$ values of $336.58 \mu \mathrm{g} / \mathrm{mL}$ and methanol with $\mathrm{LC}_{50}$ values of $315.35 \mu \mathrm{g} / \mathrm{mL}$. The results show that ethyl acetate was obtained from a combined fraction of 4 fractions, these fractions can inhibit lung ( $\mathrm{H}-460$ cells) and breast cancer (MCF-7 cells) with concentrations less than $100 \mu \mathrm{g} / \mathrm{mL}$. Some major components are identified using LC-MS also some components have not yet been identified.
\end{abstract}

Keywords: S. polycystum, MCF-7, H-460, Toxicity, Chemical Identification

RASĀYAN J. Chem., Vol. 14, No.2, 2021

\section{INTRODUCTION}

Cancer is still a disease that is a health problem in humans with an increasing number of new patients being diagnosed every year, and the mortality rate is increasing both in men and women especially in developing countries. In 2018, cancer ranked second (9,6 million) the leading cause of death from noncommunicable diseases in the global population. ${ }^{1}$ High case of cancer and cancer mortality can be caused by risk factors for diet and actions. These factors are high body mass index, lack of consumption of vegetables and fruit, lack of physical activity, smoking and excessive alcohol consumption. In general, 5 types of cancer cause death in the world, namely breast, cervical, colon, lung and stomach cancer. ${ }^{2,3}$

Among the existing cancers, lung cancer has the highest prevalence in the world. In this case, it is predicted that in 2018, the number of cases of the population in the world who suffer from lung cancer by 2,1 million and will increase every year. Lung cancer treatment is carried out in a various ways including surgery, chemotherapy, and radiotherapy, depending on the stage of the cancer sufferer. ${ }^{4}$ Surgical efforts can be done at an early stage (carcinoma in situ) stage I, and stage II, while chemotherapy can be given at an advanced stage III and several types of postoperative stage II to relieve the risk of recurrence. ${ }^{5}$

Various attempts were made to treat cancer, including using natural products. Natural products are beneficial in the development of anticancer drugs especially those derived from plants. Pharmacological studies show that herbal extracts consist of important nutrients, some compounds that have antitumor, antioxidant and anti-mutation activities with various targets that work synergistically. ${ }^{6-9}$

Plants that are known to have cytotoxic activity against cancer cells and may be used as anticancer drugs are plants from the family Phaeophyceae. Phaeophyceae are the most common group of brown algae in Indonesian waters. Several studies have shown that Phaeophyceae has the highest antioxidant activity among Rhodophyceae and Chlorophyceae. ${ }^{10,11}$ One group of brown algae that has currently been

Rasayan J. Chem., 14(2), 676-683(2021)

http://dx.doi.org/10.31788/ RJC.2021.1425976

This work is licensed under a CC BY 4.0 license. 
RASĀYAN J. Chem.

Vol. 14 | No. 2 |676-683| April - June | 2021

developed is Sargassum polycystum. Based on previous research have shown that $S$. polycystum contains bioactive compounds in the form of phenolic, terpenoids, steroids. ${ }^{12}$ Other studies have shown that methanol extracts from S. polycystum contain steroid compounds, alkaloids, phenolics, flavonoids, steroids, cardiac glycoside, saponins and sterols. ${ }^{13}$ The existence of these chemical components provide bioactivity $S$. polycystum including antioxidants, anti-cancer ${ }^{14}$, and UV Protection. ${ }^{15,16}$ Based on this information so that the study conducted an in vitro assessment of the anti-cancer activity of S. polycystum on $\mathrm{H}-460$ and MCF-7 cells from various fractions obtained.

\section{Sample Extraction}

\section{EXPERIMENTAL}

Sample S. polycystum was obtained from Dutungan Island, Barru Regency, and South Sulawesi Province, Indonesia. The sample obtained was determined by PAU laboratory, IPB University Indonesia. $S$. polycystum that has been obtained then dried in the oven at a temperature of $40^{\circ} \mathrm{C}$. The sample dry obtained was grinned by the grinder. The sample powder was then extracted by multilevel maceration using various solvents, namely n-hexane, ethyl acetate and methanol. $S$. polycystum was macerated with n-hexane solvent 3 times 24 hours and then filtered. The residue was extracted 1 times 24 hours and be strained, and then filtrate evaporated using a rotary evaporator to obtain n-hexane extract. The residue was re-extracted effectively completed with ethyl acetate and methanol in the same way.

\section{Phytochemical Screening}

Extracts were determined of the compounds by the colorimetric method using chemical reagents. Tests were carried out with specific reagents based on the method were describes by. ${ }^{17,18}$

\section{Toxicity Assay by Brine Shrimp Lethality Test (BSLT) Method}

The toxicity evaluation was carried out based on the previous methods against brine shrimp lethality dose (BSLT) with slight modification. ${ }^{19-21}$ Data of activity test were analyzed using Lethal Concentration (LC) to determine of concentration the extract could destroy A. salina by $50 \%\left(\mathrm{LC}_{50}\right)$.

\section{Fractionation of Ethyl Acetate Extract by LVC}

$$
\% \text { Mortality }=\frac{\text { total of death larvae }}{\text { total of live larvae }}
$$

The fractionation stage is carried out on $S$. polycystum which has a toxic effect on A. salina. Fractionation was carried out on ethyl acetate extract which showed great toxic effects. A total of $10 \mathrm{~g}$ of ethyl acetate extract was purified using Liquid Vacuum Chromatography (LVC) and a combination of solvents (nhexane: EtOAc: $\mathrm{MeOH}$ ) in various comparisons. Results of the merging of the fractions obtained 4 main fractions (A, B, C, D), which then carried out measurements of LC-MS and anticancer activity test.

\section{LC-MS Analysis of Ethyl Acetate Fraction}

Analysis of the chemical content of the $S$. polycystum fraction was carried out using LC-MS Bruker micrOTOF-mass spectrometer (ESI -), with conditions in the column using Cadenza $\mathrm{C}_{18}(2 \times 150 \mathrm{~mm}$ with flow $0.2 \mathrm{ml} / \mathrm{min}$ ) following conditions $0-5 \mathrm{~min} 15-60 \% \mathrm{Me}-\mathrm{CN} 0.1 \%$, formic acid, 5-7.5 min $60-70 \%$ Me-CN, $0.1 \%$ formic acid, and 7.5-10 $\min 70-80 \% \mathrm{Me}-\mathrm{CN}, 0.1 \%$ formic acid as mobile phase. Other conditions like nebulizer 0.5 bars, dry heater at $180^{\circ} \mathrm{C}$, dry gas at $4.0 \mathrm{I} / \mathrm{min}$ were prepared. The injection volume was $0.2 \mathrm{ml}$ per minute at a run time of 15 minutes. The UHPLC was associated with a triple quadrupole mass spectrometer micrOTOF equipped with an electrospray ionization interface that is set in negative mode. Analysis of compounds used software and combination with other literature.

\section{Anticancer Assay of Fraction against of H-460 and MCF-7 by MTT Method}

Anticancer assay of each fraction was done using the MTT colorimetric method by Cancer Chemopreventive Research Center ${ }^{22}$ and Dalimunthe et $a^{23}$, cisplatin was used as positive control and cell of death was calculated with the following formula: 
RASĀYAN J. Chem.

Vol. 14 | No. 2 |676-683| April - June | 2021

$$
\text { Percentage cell of death }=1-\left(\frac{\text { Abs sample }- \text { Abs media }}{\text { Abs solvent }- \text { Abs media }}\right) \times 100 \%
$$

\section{Phytochemical Screening}

\section{RESULTS AND DISCUSSION}

Phytochemical screening results were carried out from each extract of maceration results using various solvents, hexane, ethyl acetate, and methanol. Phytochemical screening is carried out using specific color reagents. Table-1 shows that n-hexane $S$. polycystum extract contains secondary metabolites in the form of terpenoids, steroids, while the extract of methanol and ethyl acetate $S$. polycystum each contains phenolic metabolites, terpenoids and steroids. Similar results were obtained from the study of Arsianti et $a l$ which also shows the presence of phenolic compounds, terpenoids, steroids.

Table-1: Phytochemical Screening of S. polycystum Extract

\begin{tabular}{c|c|c|c|c|c|c}
\hline S. polycystum & Alkaloid & Flavonoid & Phenol & Saponin & Terpenoid & Steroid \\
\hline Methanol & - & - & + & - & + & +++ \\
\hline Ethyl acetate & - & + & ++ & - & + & +++ \\
\hline n-Hexane & - & - & - & - & + & +++ \\
\hline
\end{tabular}

$(+)$ means positive results (++ and +++$)$ means dominant compound, (-) means of negative results.

\section{Toxicity Assay of $\boldsymbol{S}$. polycystum Extract by BSLT Method}

Initial screening for bioactivity each extract results were tested for toxicity using the Brine Shrimp Lethality Toxicity (BSLT) method. BSLT testing is an acute toxicity test conducted to determine the toxic effects after dosing within 24 hours. The results of the toxicity test using the BSLT method are express in $\mathrm{LC}_{50}$ value, which indicates the amount of concentration needed to destroy $50 \%$ of the larval of Artemisia salina shrimp population. The study of Nur et al indicated that a sample was declared toxic if it had an $\mathrm{LC}_{50}$ value below $1000 \mu \mathrm{g} / \mathrm{mL}{ }^{24}$ The results of the toxicity test of each extract with various concentrations provide an overview of the toxic effects of A. salina (Table-2).

\begin{tabular}{|c|c|c|}
\hline Concentration $(\mu \mathrm{g} / \mathrm{mL})$ & Mortality $(\%)$ & $\mathrm{LC}_{50}(\mu \mathrm{g} / \mathrm{mL})$ \\
\hline \multicolumn{3}{|c|}{ Methanol Extract } \\
\hline 200 & $33.33 \pm 5.77$ & $\mathrm{R}^{2}=0.9493$ \\
\hline 400 & $53.33 \pm 5.77$ & $\mathrm{LC}_{50}=315.35$ \\
\hline 600 & $63.33 \pm 11.54$ & \\
\hline 800 & $76.67 \pm 5.77$ & \\
\hline 1000 & $83.33 \pm 5.77$ & \\
\hline \multicolumn{3}{|c|}{ Ethyl Acetate Extract } \\
\hline 10 & $43.33 \pm 11.54$ & $\mathrm{R}^{2}=0.9901$ \\
\hline 20 & $66.67 \pm 5.77$ & $\mathrm{LC}_{50}=12.37$ \\
\hline 30 & $76.67 \pm 5.77$ & \\
\hline 40 & $83.33 \pm 11.54$ & \\
\hline 50 & $90.00 \pm 10.00$ & \\
\hline \multicolumn{3}{|c|}{ n-hexane Extract } \\
\hline 100 & $16.67 \pm 5.77$ & $\mathrm{R}^{2}=0.9628$ \\
\hline 200 & $26.67 \pm 5.77$ & $\mathrm{LC}_{50} 364.08$ \\
\hline 300 & $43.33 \pm 11.54$ & \\
\hline 400 & $53.33 \pm 5.77$ & \\
\hline 500 & $63.33 \pm 5.77$ & \\
\hline
\end{tabular}

Table-2 shows that $S$. polycystum ethyl acetate extract has a very toxic activity with $\mathrm{LC}_{50}$ values 12.37 $\mu \mathrm{g} / \mathrm{mL}$ while methanol and $\mathrm{n}$-hexane with $\mathrm{LC}_{50}$ values of 315.35 and $364.08 \mu \mathrm{g} / \mathrm{mL}$ respectively. Based on the results show that the extract of $S$. polycystum was toxic activity because it has an $\mathrm{LC}_{50}$ value $<1000$ $\mu \mathrm{g} / \mathrm{mL}$. 
RASĀYAN J. Chem.

Vol. 14 | No. 2 |676-683| April - June | 2021

\section{Characterization by LC-MS Method}

Identification of metabolites using LC-MS from various fractions equipped with a micro to-Bruker mass spectrometer with a negative mode. Four fractions of LVC results have been identified using LC-MS analysis and chromatograms can be seen in Fig.-1.

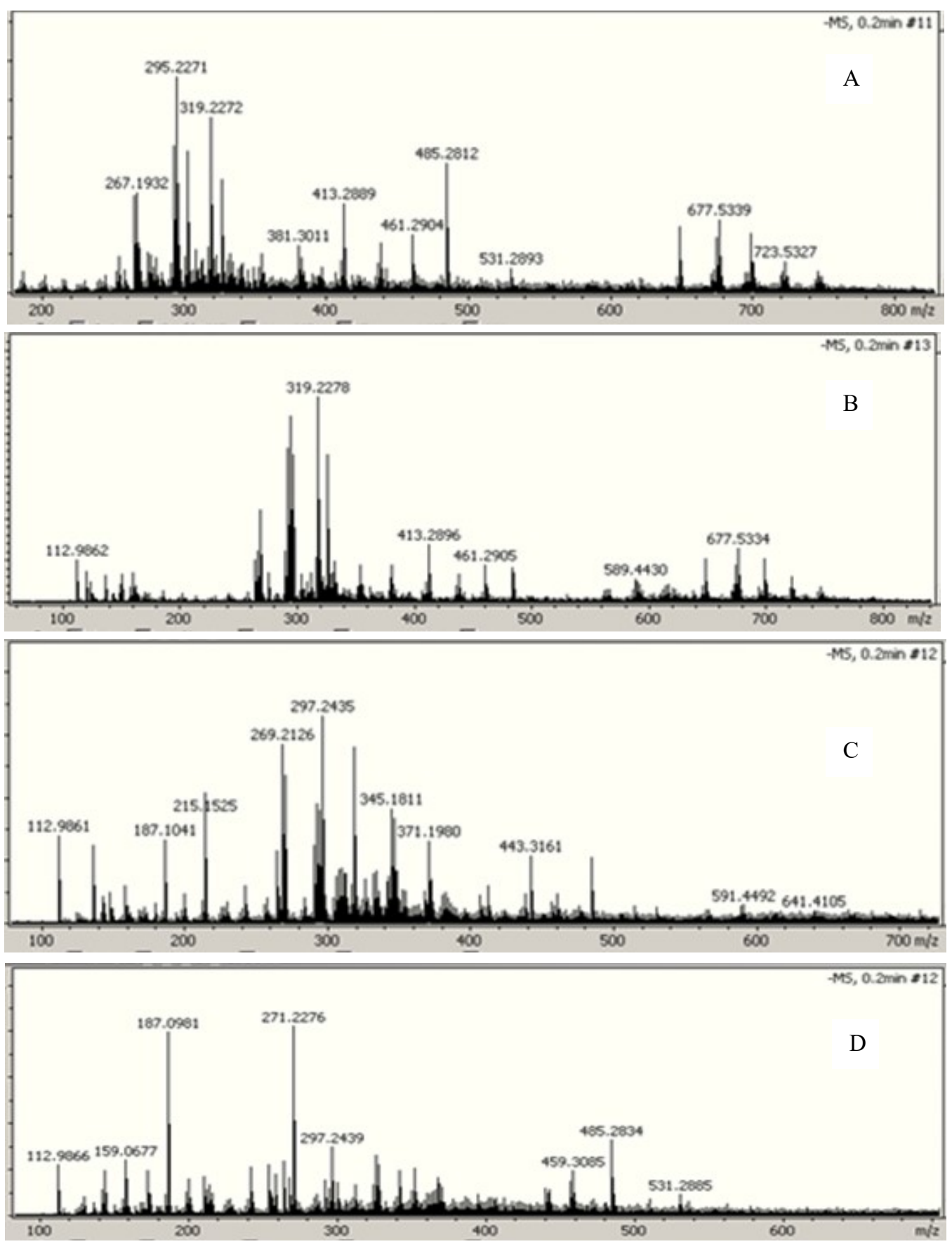

Fig.-1: MS Profile S. polycystum Fractions (A, B, C and D) with M-H Mode

Identification of the structure was carried out using literature data on Marine Natural Products Compounds, by the similarity of structural formulas and molecular mass the closest to the MS-spectra. Prediction of compounds can be observed in Table-3.

The data from Table-3 shows some fractions have similar chemical component predictions from each fraction. It is known that in Fraction A, there were 7 predictions of chemical components, Fraction B had 
RASĀYAN J. Chem.

5 chemical components, Fraction $\mathrm{C}$ contained 10 types of chemical components, and Fraction D obtained 10 predictions of chemical components. The four fractions generally have similar component compounds, namely 2-Furoic Acid $(112 \mathrm{~m} / \mathrm{z}), \beta$-sitosterol, fucosterol $(413 \mathrm{~m} / \mathrm{z})$. Prediction of compounds in each fraction is thought to be a group of phenolic compounds, flavonoids, steroids and terpenoids. This is similar to the phytochemical screening of S. polycystum that contains classes of these compounds.

Table-3: LC-MS Profile of $S$. polycystum Fraction in Negative Mode

\begin{tabular}{|c|c|c|c|}
\hline Fraction & $\mathrm{m} / \mathrm{z}$ & Compound & Class \\
\hline $\mathrm{A}, \mathrm{B}$ & 677 & $\begin{array}{l}\text { 10-carboxyl-pyranopeonidin 3-O-(6"-O-p- } \\
\text { coumaroyl)-glucoside }\end{array}$ & Glycoside Flavonoids \\
\hline $\mathrm{B}, \mathrm{C}$ & 591 & 16-oxo-alisol A 24-actetate & Triterpenoid \\
\hline $\mathrm{C}, \mathrm{D}$ & 531 & Phytolaccagenin & Terpenoid \\
\hline $\mathrm{A}, \mathrm{D}$ & 485 & Alisol C & Steroid \\
\hline $\mathrm{B}$ & 461 & Fucofurodiphlorethol & Fenolik \\
\hline $\mathrm{D}$ & 459 & Quercetin-O-pentoside & Flavonoids \\
\hline $\mathrm{C}$ & 443 & Thunbergol A, B & Terpenoid \\
\hline $\mathrm{A}, \mathrm{B}, \mathrm{C}, \mathrm{D}$ & 413 & $\beta$-sitosterol, fucosterol & Steroid \\
\hline $\mathrm{A}$ & 381 & Heptacoxane & Lipid \\
\hline $\mathrm{C}$ & 345 & $\begin{array}{c}\text { [6-ethyl-3,4-dimethyl-(tetrahydro-20,20,60- } \\
\text { trimethyl-2H-pyran-30-yl)-2,5-cycloheptadiene]-1- } \\
\text { propanoate }\end{array}$ & Fatty acid \\
\hline $\mathrm{D}$ & 327 & Ophiopogonanone & Phenol \\
\hline $\mathrm{B}$ & 319 & $p$-Coumaroylshicimic acid & Phenol \\
\hline $\mathrm{C}, \mathrm{D}$ & 297 & nd & \\
\hline $\mathrm{A}$ & 295 & Tanacetol B, Embelin, Phytol & Terpenoid \\
\hline $\mathrm{C}$ & 291 & Brevifolin carboxylate & Phenol \\
\hline $\mathrm{D}$ & 271 & Hexadecanoic acid & Lipid \\
\hline $\mathrm{C}$ & 269 & 6,10,14-trimethyl-2-pentadecanoic acid & Lipid \\
\hline $\mathrm{C}$ & 215 & nd & \\
\hline $\mathrm{D}$ & 211 & Norisoprenoid derivative & Terpenoid \\
\hline $\mathrm{C}, \mathrm{D}$ & 187 & nd & \\
\hline $\mathrm{A}, \mathrm{D}$ & 159 & nd & \\
\hline $\mathrm{A}, \mathrm{B}, \mathrm{C}, \mathrm{D}$ & 112 & 2-Furoic acid & Phenol \\
\hline
\end{tabular}

\section{Anticancer Activity against MCF-7 and H-460 Cell}

Anti-cancer activity testing of MCF-7 and H-460 cells from each S. polycystum fraction was carried out in vitro to describe dead cells using the colorimetric method specifically by MTT \{3- (4,5-dimethyltiazol-2il) 2,5 -diphenyl tetrazolium bromide $\}$ on Microplate Reader with a wavelength of $570 \mathrm{~nm}$. MTT method is a method that can be used to measure the percentage of cell death based on mitochondrial activity from inside a cancer cell. ${ }^{25}$ The principle of this measurement is based on the formation of color after cells have reacted with MTT reagents. The MTT color which was originally yellow will reduce to purple or blue due to the formation of formazan crystals.

This test carried out using four fractions namely fraction A, B, C, and D. Cytotoxic activity of each fraction is expressed in percentage cytotoxic. The classified cytotoxic activity towards cancer cells shows that $\mathrm{IC}_{50}$ values less than $20 \mu \mathrm{g} / \mathrm{mL}$ showed strong activity, while $\mathrm{IC}_{50}$ values of $20-100 \mu \mathrm{g} / \mathrm{mL}$ showed moderate activity and then $\mathrm{IC}_{50}$ values of $100-1000 \mu \mathrm{g} / \mathrm{mL}$ showed weak activity. Cytotoxic activity testing was carried out with a level series of $10 ; 100 ; 1000 \mu \mathrm{g} / \mathrm{mL}$. The results showed that each $S$. polycystum fraction provided anticancer activity from strong to moderate. Data on cytotoxic activity of each fraction against MCF-7 and H-460 cells can be observed in Fig.-2.

Figure-2 shows that the fractions C and D in S. polycystum with a concentration of $10 \mu \mathrm{g} / \mathrm{ml}$ gave percent cell death above $50 \%$ respectively 70.53 and $76.4 \%$ whereas in fractions A and B gave percent cell death below $50 \%$ with a value of 42.37 and $22.29 \%$. At a concentration of $100 \mu \mathrm{g} / \mathrm{ml}$ each fraction was able to give cell death above $50 \%$. Fraction $\mathrm{C}$ had the highest cell death activity with a mortality rate of $98.33 \%$ followed by fraction B $(90.38 \%)$, Fraction D $(84.4 \%)$ and fraction A $(54.63 \%)$. The results of the 
RASĀYAN J. Chem.

Vol. 14 | No. 2 |676-683| April - June | 2021

percentage of $\mathrm{H} 460$ cancer cell death show that fractions $\mathrm{C}$ and $\mathrm{D}$ have activities that are categorized as very strong with the level of $10 \mu \mathrm{g} / \mathrm{mL}(<20 \mu \mathrm{g} / \mathrm{mL}){ }^{26}$

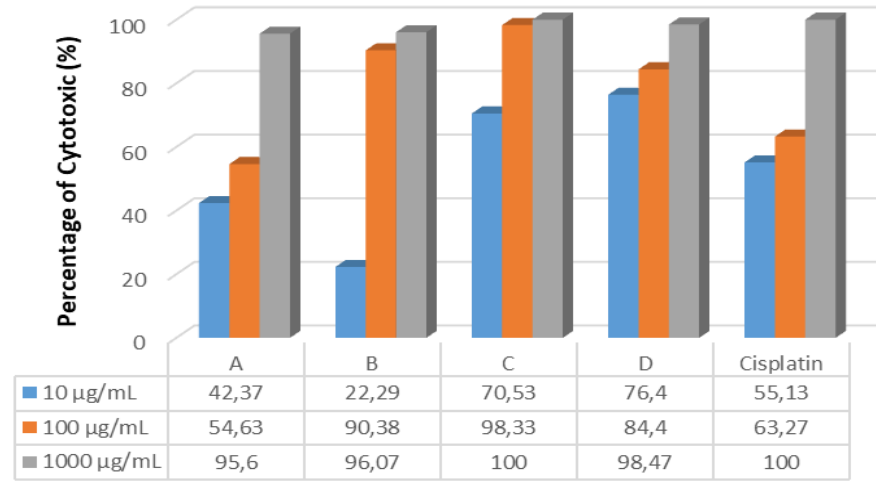

Fig.-2: Anticancer Activity of Fraction of S.polycystum against H-460 Cell

The same thing was done for MCF-7 cancer cells using 4 fractions (Fig.-3). The results showed that fractions A, C and D at concentrations of $10 \mu \mathrm{g} / \mathrm{ml}$ gave death activity in MCF-7 cells above $50 \%$ with the percentage values of cell death respectively $63.1 \%, 66.5 \%$, and $67.73 \%$ which categorized as having very strong inhibition while fraction $\mathrm{B}$ was categorized as a moderate activity where at a concentration of $100 \mu \mathrm{g} / \mathrm{ml}$ gave a percent of cell death of $66.33 \%$. This research shows that fractions C and D provide good cytotoxic activity against H-460 and MCF-7 cells which are categorized as a very strong activity. While fraction A provides cytotoxic activity against MCF-7 cells with a very strong category. Unlike the case with fraction B which only gives cytotoxic to H-460 and MCF-7 cells with the moderate category. With the existence of cytotoxic activity of fractions towards H-460 and MCF-7 cells due to the activity of each component of the compound. Based on the results of the prediction of compounds using LC-MS stated that each fraction contains classes of compounds flavonoids, phenolic, steroids and terpenoids. Flavonoid and phenolic are known to have anti-cancer activity by inducing apoptosis while simultaneously inducing cell differentiation. ${ }^{27-29}$ For groups of steroid/terpenoid compounds can reduce the progression of cancer cells.

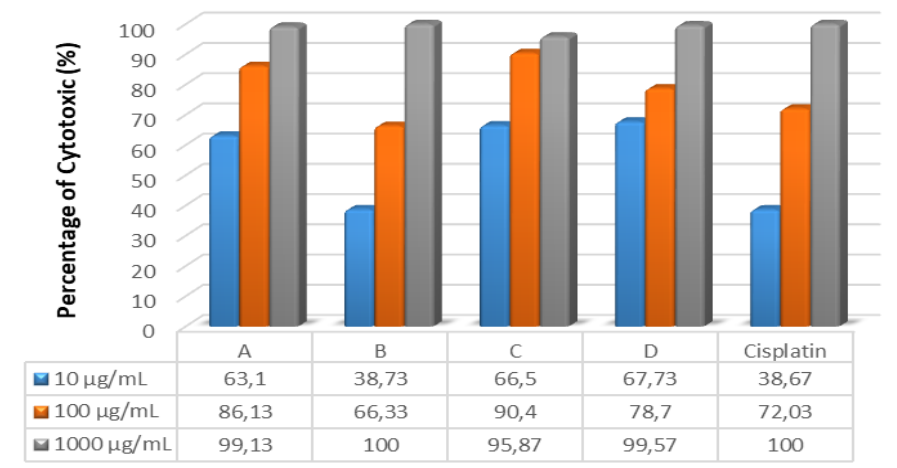

Fig.-3: Anticancer Activity of Fraction of S.polycystum against MCF-7

\section{CONCLUSION}

Investigations regarding extracts from $S$. polycystum revealed that extract could be developed as a basis for the development of anticancer drugs. The toxicity test for $A$. salina obtained by ethyl acetate extract has a very strong toxic effect. The fractions of ethyl acetate extract have the potential to be anticancer in lung and breast cancer cells in vitro. Also, this study provides an identification of compounds contained in ethyl acetate fraction.

\section{ACKNOWLEDGEMENT}

The researcher could like to thank the Indonesia Ministry of Research, Technology, and Higher Education (KEMENRISTEK DIKTI) for the dissertation research funding 2020. 
RASĀYAN J. Chem.

Vol. 14 | No. 2 |676-683| April - June | 2021

\section{REFERENCES}

1. S. Hyuna, F. Jacques, S.L. Rebecca, L. Mathieu, S. Isabbele, J. Ahmedin and B. Freddie, A Cancer Journal for Clinicians, 1, 1(2021), DOI:10.3322/caac.21660

2. H.H. Sokkar, A. S. Abo Dena, N. A. Mahana and A. Badr, Future Journal Pharmaceutical Science, 6, 78(2020), DOI: 10.1186/s43094-020-00088-0

3. M.S. Islam, M.S. Rahi, C.A. Jahangir, M.H. Rahman, I. Jerin, R. Amin, K.M.F. Haque and M.A. Reza, Evidence-based Complementary Alternative Medicine, 11, 1537896(2018), DOI: $10.1155 / 2018 / 1537896$

4. World Health Organization, Indonesia Source Globocan, 256:1-2(2018)

5. R. Dienstmann, R. Salazar and J. Tabernero, Journal of Clinical Oncology, 33(16), 1787(2015), DOI: $10.1200 / \mathrm{JCO} .2014 .60 .0213$

6. T.M. Kalappurayil and B.P. Joseph, Pharmacognosy Journal, 9(1), 1(2017), DOI: $10.5530 / \mathrm{pj} .2017 .1 .1$

7. A. Leone, A. Spada, A. Battezzati, A. Schiraldi, J. Aristil and S. Bertoli, International Journal of Molecular Sciences, 16(6), 12791(2015), DOI:10.3390/ijms160612791

8. Shanmugapriya, Y. Chen, J.R. Kanwar and S. Sasidharan, Asian Pacific Journal of Tropical Disease, 69(8), 1308(2016), DOI: 10.1016/S2222-1808(15)61033-7

9. B. Gogoi, D. Gogoi, Y. Silla, B.B. Kakoti and B.S. Bhau, Molecular Biosystem, 13(2), 406(2017), DOI: $10.1039 / \mathrm{c} 6 \mathrm{mb} 00807 \mathrm{k}$

10. K. Chakraborty and D. Joseph. Journal of Aquatic Food Product Technology, 25(8), 1249(2016), DOI: $10.1080 / 10498850.2015 .1054540$

11. L.R.G. Kumar, Journal of Food Processing and Preservetion, 44(9), 14769(2020), DOI: $10.1111 /$ jfpp. 14716

12. F.J. Sami, N.H. Soekamto, F. Firdaus and J. Latip, Jurnal Kimia Riset, 4(1), 1(2019), DOI: $10.20473 / \mathrm{jkr} . \mathrm{v} 4 \mathrm{i} 1.10903$

13. M. Johnson, S. Asha Kanimozhi, T.J.M. Renisheya Joy, T. Shibila, P.R Freitas, S.R Tintino, I.R.A, Menezes, J.G.M, da Costa and H.D.M, Coutinho, Complementary Therapies in Medicine, 46, 19(2019), DOI:10.1016/j.ctim.2019.06.014

14. A. Arsianti, A. Bahtiar, V.K. Wangsaputra, N.N. Azizah, W. Fachri, L.D. Nadapdap, A.M. Fajrin, H. Tanimoto and K. Kakiuchi, Pharmacognosy Journal, 12(1), 88(2020), DOI: $10.5530 / \mathrm{pj} .2020 .12 .14$

15. S. A. Budhiyanti, S. Raharjo, D.W. Marseno and I.Y.B. Lelana, American Journal of Agricultural and Bioogical Sciences, 7(3), 337(2012), DOI:10.3844/ajabssp.2012.337.346

16. Y.H. Sipahutar, N. Albaar, H.B. Purnamasari, M.G. Kristiany and D.H.G. Prabowo, IOP Conference Series: Earth and Environmental Science, 278(1), 012072(2019), DOI: $10.1088 / 1755-1315 / 278 / 1 / 012072$

17. J.B. Harborne, Phytochemical Methods A Guide to Modern Tecniques of Plant Analysis, Third Edition, Chapman Hall, New York, p. 279(1998), DOI: 10.1017/CBO9781107415324.004

18. G. Saragih, Tamrin, Marpongahtun and D.Y. Nasution, Rasayan Journal of Chemistry, 13(1), 476(2020), DOI: 10.31788/RJC.2020.1315524

19. Supomo, E.S. Syamsul, A. Apriliana, C. Saleh, Erwin and D. Lestari, Rasayan Journal of Chemistry, 12(3), 1340(2019), DOI: 10.31788/RJC.2019.1235264

20. N. Syamsu, F. Mubarak, C. Jannah, D.A. Winarni, D.A. Rahman, L.A. Hamdayani and F.J Sami, Food Research, 3(6), 734(2019), DOI:10.26656/fr.2017.3(6).135

21. D.G.R. Aruan, T. Barus, G. Haro and P. Simanjuntak, Rasayan Journal of Chemistry, 12(2), 947(2019), DOI: 10.31788/RJC.2019.1225204

22. Cancer Chemoprevention Research Center, Prosedur Tetap Uji Sitotoksik Metode MTT, Pharmacy UGM, Yogyakarta, p. 6(2013)

23. A. Dalimunthe, P.A.Z. Hasibuan, M. Fujiko, Masfria and D. Satria, Rasayan Journal of Chemistry, 14(1), 16(2021), DOI: 10.31788/RJC.2021.1415734

24. B.N. Meyer, N.R. Ferrigni and J.E. Putnam, Planta Medica, 45(5), 31(1982), DOI: $10.1055 / \mathrm{s}-2007-971236$ 
RASĀYAN J. Chem.

Vol. 14 | No. 2 |676-683| April - June | 2021

25. T. Bernas and J. Dobrucki, Cytometry, 47(4), 236(2002), DOI:10.1002/cyto.10080

26. K. Atjanasuppat, W. Wongkham, P. Meepowpan, P. Kittakoop, P. Sobhon, A. Bartlett and P.J. Whitfield, 123(3), 475(2009), DOI:10.1016/j.jep.2009.03.010

27. T. Yang Wang, Q. Li and K. Shun Bi, Asian Journal of Pharmaceutical Sciences, 13(1), 12(2018), DOI: 10.1016/j.ajps.2017.08.004

28. J. Iqbal, B.A. Abbasi, T. Mahmood, S. Kanwal, B. Ali, S.A. Syah and A.T. Khalil, Asian Pacific Journal of Tropical Biomedicine, 7(12), 1129(2017), DOI:10.1016/j.apjtb.2017.10.016

29. H. Sakagami, Y. Jiang, K. Kusuma, T. Atsumi, T. Ueha, M. Toguchi, I. Iwakura, K. Satoh, H. Ito, T. Hatano and T. Yoshida, Phytomedicine, 7(1), 39(2000), DOI:10.1016/S0944-7113(00)80020-3

[RJC-5976/2020] 